\title{
13 Queer Translation as Performative and Affective Un-doing
}

\author{
Translating Butler's Undoing \\ Gender into Italian
}

\section{Michela Baldo}

This contribution aims to theorize the interconnections between queer theory and translation by focusing on the discourses surrounding the recent translation into Italian of Judith Butler's Undoing Gender (2004c) by Federico Zappino with the title Fare e disfare il genere (2014) [Doing and Undoing Gender].

Fare e disfare il genere is the retranslation of a previous translation into Italian of the same work by Butler, La disfatta del genere (2006), [Gender's Defeat] whose title suggested a hypothetical "defeat" (disfatta) instead of the concept of renegotiation, of a "doing" (fare) and "undoing" (disfare), which the retranslation aims to foreground. Thinking about gender as undoing offers useful theoretical insights for translation studies, as it brings to the fore the still under-researched concepts of performativity and affect, which play a fundamental role in many translation processes. The insistence on affect and relationality is also found in many reviews of Fare e disfare il genere, often written by activists who participated in the debates taking place in various venues during the book presentations. ${ }^{1}$ The article will explore how these concepts can help to conceptualize "queer" translation and to highlight the productivity of associating the term "queer" with the notion of translation. ${ }^{2}$

\section{Doing and Undoing Gender}

Fare e disfare il genere is not the first retranslation of Butler's work in Italian. In 2013, Zappino retranslated for publisher Mimesis The Psychic Life of Power: Theories in Subjection (1997) as La vita psichica del potere. Teorie del soggetto [The Psychic Life of Power. Theories of the Subject] (Butler 2013a), previously translated for Meltemi in 2005 as La vita psichica del potere. Teorie della soggettivazione e dell'assoggettamento [The Psychic Life of Power. Theories of the Subject and of Subjection]. In that same year, Olivia Guaraldo retranslated for Postmedia books Precarious Life: The Powers of Mourning and Violence (2004a), as Vite precarie. I poteri del lutto e della violenza [Precarious lives. The powers of mourning and violence] (Butler 2013c), previously translated for Meltemi in 2004 with the 
title Vite Precarie. Contro l'uso della violenza in risposta al lutto collettivo [Precarious Lives. Against the Use of Violence as an Answer to Collective Mourning] (Butler 2004d). Finally, again in 2013, Sergia Adamo retranslated for Laterza Gender Trouble: Feminism and the Subversion of Identity (1990), with the title Questione di genere. Il femminismo e la sovversione dell'identità [The Issue of Gender. Feminism and the Subversion of Identity], which was previously translated in 2004 as Scambi di genere. Identità, sesso e desiderio [Gender Swaps. Identity, Sex and Desire] (Butler 2004b), by Roberta Zuppet for publisher Sansoni.

If the translations of Butler's works, which have increased in recent years, show renewed interest in her theories, the retranslations are a curious phenomenon, given the presence of so many of them in such a short time span. A simple reason for this can be found, at least in the case of Fare e disfare il genere, La vita psichica del potere and Vite precarie, in the fact that Meltemi, the publishing house which had published these first translations of Butler, had ceased its activities in 2010 and the publishing houses Mimesis and Postmedia books, after acquiring its inventory, wanted to republish and rebrand some of Meltemi's previous publications. Similarly, in the case of Scambi di genere. Identità, sesso e desiderio (2004b), Laterza wanted to make available again a seminal book by Butler, which had been out of print with publisher Sansoni.

The choice of Butler was dictated by the fact that she had regained popularity in the preceding years judging from the number of translations, a total of four, published between the years 2009 and 2012. If this popularity might have been linked to the fact that she was awarded the prestigious Adorno prize in 2012, it is also partially due, as this chapter will demonstrate, to the increased circulation of queer theory in Italy in the same or preceding years, thanks to various Italian collectives and groups. These are, to name a few, Laboratorio Smaschieramenti (URL) from Bologna, which, since 2007, has been doing critical work on masculinity through the lens of queer theory, and a collection like altera, born in 2010 within the publishing house ETS and directed by Italian queer theorists Marco Pustianaz and Liana Borghi.

Another reason for the retranslations of Butler's works might be ascribed to the intensification of public discourses around the so-called teoria del gender [gender theory] in Italy in the last 10-15 years. "teoria del gender" 3 is a label coined by the Church in the year 2000, and has been used by Catholic and other groups (which I will label in this chapter as anti-gender movements) to delegitimize research done in gender studies, and to oppose the denaturalization of gender and sexuality categories undertaken within them (Garbagnoli 2014), especially in Butler's theorizations, as this research was perceived as seriously threatening the symbolic heteronormative order of society based on hierarchical gender binarism (male versus female).

If Butler's retranslations came about due to the ripe conditions for the circulation of work on queer theory, and from the attempt to make the work of an already popular philosopher available again under a new publisher's name, this re-branding also underscores the need for retelling, expanding, 
and redefining aspects of her theories in view of current public debates. This is the case, for example, with Sergia Adamo's retranslation of Gender Trouble in which the publisher ${ }^{4}$ replaces scambi, or "swaps," "exchanges" in the title with questione, or "issue," "question" to better illustrate the troubling aspect of questioning (the disturbance, the confusion as stated in the translator's preface) (see SIL 2013) given the paradigms of gender and sexuality discussed in Butler's work; this is also the case with Guaraldo's ${ }^{5}$ retranslation of Vite precarie, in which phrases like "to be beside oneself" were retranslated as "essere fuori di sè, essere fuori di se stessi" [to be outside oneself] (Butler 2013c: 49) as opposed to the previous "essere al fianco di se stessi" [to be at the side of oneself] (Butler 2004a: 44-46).

This retelling is not only present in the retranslation of Undoing Gender (as will become evident later in this chapter), but it is also confirmed by the paratextual material accompanying it, such as the afterword written by Zappino. Also La vita psichica del potere. Teorie del soggetto (2013a), mentioned earlier, included additional paratextual material, such as the translation of a dialogue between Butler and Adam Philips, as well as an afterword in the form of a dialogue between Zappino and Lorenzo Bernini. This afterword represented an occasion for the two philosophers to depart from Butler in order to discuss antisocial queer theories, taking as their inspiration Bernini's book Apocalissi Queer [Queer Apocalypses](2013), which came out soon after the publication of the translation. I would like, therefore, to take this need for retelling as my point of departure in discussing Zappino's Fare e disfare il genere (2014).

As stated by Butler, the book revolves around not only what it means "to undo restrictively normative conceptions of sexual and gendered life" but also "the experience of becoming undone" (2004c: 1) - that is, to be "undone by grief, gender, desire, and the Other," as pointed out by some reviewers (Schoch Zavaletta 2005: 152). The movement of undoing, however, presupposes a doing, an activity performed as a sort of "improvisation within a scene of constraint" (Butler 2004c: 1), which Butler had widely discussed in Gender Trouble as part of the broader concept of gender performativity.

In retranslating Undoing Gender, therefore, it seems more appropriate to use two terms like fare e disfare (doing and undoing) to translate "undoing," a choice which was agreed upon by Zappino in consultation with Butler, rather than disfatta [the act of being undone, defeat], chosen in the previous Italian translation. Although hinting at the action of "gender becoming undone" as a transformative moment in time leading to new beginnings, as stated by the translator Olivia Guaraldo ${ }^{6}(2014)$ in the preface to her translation, disfatta also recalls, according to Zappino, ${ }^{7}$ the idea of the defeat and themes associated with it, like death, killing, and ending, rather than the concept of renegotiation and fluidity invoked by the movement between doing and undoing. Because of this ambiguity, Zappino felt the need for a new translation of the title and an undoing and redoing of 
some passages of the previous translation. ${ }^{8}$ Zappino claimed that he revised them by stressing more the concept of doing and undoing present in the title, referring, for example, to the condition of being undone in the experience of falling in love.

In Brescia, Italy, in March 2015, at one of many book presentations, Zappino (2015) said that in Undoing Gender, Butler tries to undo (as she will keep doing on various occasions after that) the "illusions" and misinterpretations that her theories had produced at a discursive level in the years following the publication of her first works, Gender Trouble (1990) and Bodies That Matter (1993).9 Already in 1993, with Bodies That Matter, Butler tried to clarify that gender performativity did not refer to one's choice of performing gender as one's likes, but rather to mimicking or imitating the dominant conventions of gender imposed by the heteropatriarchal system in which one lives. Moreover, she stressed the materiality of the body, which, according to her critics, appeared to have been previously dismissed. However, Butler, who had already emphasized the power of discourse in forming the matter of bodies, sex, sexuality, and gender (therefore pointing to the importance of said materiality), replies in the second half of Undoing Gender to those who had critiqued her theory as apolitical voluntarism, saying that her approach to the subject had surely been political because she had moved in the direction of unsettling socially constructed heteronormative conceptions of gender and sexuality in line with feminist political calls for social transformation..$^{10}$ In this book, Butler is indeed especially interested in looking at the new gender politics that have emerged in recent years, that is, "the combination of movements concerned with transgender, transsexuality, intersex, and their complex relation to feminist and queer theory" (2004c:4).

However, the main aim of Undoing Gender is not to undo previous misinterpretations of Butler's work but rather, as stated earlier, to undo-or to talk about how to undo-restrictive social norms regarding gender and sexuality. Zappino, at the aforementioned book presentation, defines the concept of undoing as being both negative and positive. The negative part refers to the feeling by queer subjects of being "undone" by their non-conforming to dominant gender and sexuality norms, of not being fully recognizable given that "the terms by which they are recognized make their life unliveable" (Butler 2004c: 3). The positive part, however, refers to the possibilities opened up by this undoing. Gender is never something that we do alone. As Butler states, "one is always doing with or for another, even if the other is always imaginary [...] But the terms that make up one's own gender are from the start outside oneself, beyond oneself, in a sociality that has no single author" (2004c: 1). She continues, "One is dependant on the outside to lay claim to what is one's own. The self must be dispossessed in sociality in order to take possession of itself" (2004c: 7).

Since gender is something we do with other people, it follows that it can't be possessed but rather it possesses or dis-possesses us. This condition is 


\section{2}

named by Butler as the condition of the "ec-static subject." Since we are relational subjects, we can't imagine ourselves outside a web of relations. However, these relations decenter us, they bring us outside or even beside ourselves. As stated by Butler, "we are undone by each other. And if we're not, we are missing something" (2004c: 19). Therefore, it is in this undoing, in this loss, that a possibility for transformation is found, a transformation and recreation of new parameters of intelligibility, subjectivity, and thus livability that can exceed the consolidated ones.

Thinking about gender as something we $d o$ and undo together with others provides interesting insights for a discussion of the translation of Butler's Undoing Gender, but also for translation in general—on the one hand, because it makes us think of translation as constant circular movements of "to and fro," and on the other, because it invokes the idea that translation is a dialogic activity. These concepts will be discussed more thoroughly in the subsequent sections.

\section{Translation, Performance, and Performativity}

Since the cultural turn in the 1990s and the more recent sociological turn in the discipline (Angelelli 2012), the last two decades of translation studies have conceptualized translation as a creative activity (Bassnett and Lefevere 1990; Bassnett and Bush 2006) and as a political and transformative one (Tymoczko 2007, 2010; Baker 2006, 2013).

Considering translation as a creative activity connects us to the idea of authorship discussed by Butler in relation to gender, which is constituted in "a sociality that has no single author" (Butler 2004c: 1). The notion of authorship is thus challenged and scattered. This can be easily applied to translation. Translation is no longer seen in traditional terms as a reproductive and derivative activity, a copy (often bad) of an "original" or "authorial" discourse transported from one language to another, but as a creative operation, authorial in its own terms. Drawing again on Butler's seminal work on gender performativity (1990), we can say that translation is a copy of an original that does not exist, and thus originality and authorship become illusions.

This reformulated idea of authorship is linked to the concept of performativity theorized by Butler, who draws on speech acts theory by J.L. Austin and Jacques Derrida's notion of "iterability," and which has been investigated by such scholars of translation studies as Keith Harvey, Luise von Flotow, Douglas Robinson, and Sandra Bermann. Their interest in performativity follows a growing interest in a concept that has been mainly associated with theater translation, to the point that scholars of theater translation, such as Silvia Bigliazzi et al. (2013), refer to a "performative turn" in translation studies. For example, Harvey states that "the notion of performativity seems to have led translation researchers to focus largely on the role played by theatricality and linguistic markers in dialogue that signify gayness" (Harvey 1998: 305). Butler (1990) had indeed paralleled the 
notion of gender performance with "the performance, by different actors, of the same (predictable, conventional, prescribed, rarely radical) script" (von Flotow 2012: 132).

However, performativity exceeds the boundaries of the theatrical field. Robinson (2003), also drawing on Derrida's idea of iterability and Austin's (1962) speech acts theory, sees translation as a series of re-performed acts (spoken or written), which change by virtue of their reiteration in new contexts. Translation can never be a reproduction of past speech acts but is rather a reinvention of them. Both Robinson and Bermann see the performative aspect of translation lying in the fact that, as a speech act, translation does or produces something. For Robinson (2003), translation does something to its audience. Bermann (2014), in the same vein, states that translation is the product of a set of repeated acts in the same way the gendered subject is, given that gender, according to Butler, "is not what one is but rather what one does" (Bermann 2014: 290). However, if performativity is a matter of doing, and we are bound to perform the roles assigned to us by the normative system, "there is also a possibility of resistance and displacement," as "there are gaps, slippages, openings that might be used to question and disrupt this gender-binding repetition" (Bermann 2014: 291). Bermann, drawing on Butler but also on Derrida's notion of iterability, states that the performative has to do with the creation of something new, that is, the notion of creativity mentioned earlier. This is possible since the notion of iterability implies that language is citational, a repetition of something else. This repetition undermines the authors' intentions as it inserts something else into those intentions, a sort of "dehiscence" or "cleft" (Derrida 1985: 18 ) into the subject's intended meaning. If we apply this to translation, we can see both its non-derivative status in relation to an original, which is already a citation of something else, but also its inaugural status in "the making of something new" (Bermann 2014: 289).

Translation is thus performative as it is a doing, but, by virtue of its iterability, it becomes a constant doing and undoing. This back and forth movement is what makes transformation possible, as translation-by infusing target language with otherness-disrupts both the source and the target language. Butler herself talks about this transformative and translational process in Undoing Gender by making specific reference to cultural translation. She states that cultural translation does not mean assimilating into our own foreign and unfamiliar notions (in the specific case categories such as being human, being gendered, and being sexualized) but rather "yielding our most fundamental categories, that is, seeing how and why they break up" (Butler 2004c: 38). And again, cultural translation is not about "translation between two languages that stay enclosed, distinct, unified. But rather, translation will compel each language to change in order to apprehend the other" (Butler 2004c: 38). Translation is, in this sense, a dialogic activity that cannot avoid some sort of fictional or factual relationship with an "other" (be it a source text, a source image, etc.). 
But what exactly do we mean by the other or by otherness? As Bermann states, Butler explains this in the opening chapter of her book Parting Ways: Jewishness and the Critique of Zionism (2012). Here, according to Bermann, translation "acts as a model for political and ethical relationality" (2014: 294), an allegory for the way in which hegemonic cultures can be transformed, undone, by the encounter with otherness. Translation implies an ethical stance, as the encounter with otherness "interrupts our sense of selfhood and expands our capacity to imagine the human" (Bermann 2014: 295). In a talk on translation given by Butler (2016) at California College of the Arts, she argues that translation is not only about realizing the contingency of the language we speak but also the possibility of seeing ourselves faltering in another language. ${ }^{11}$ Translation is thus a transformative activity as it positions itself in a critical relation to power and plays a primary role in processes of social transformation.

\section{Authorship, Performativity, and Affect in Fare e disfare il genere}

In light of what has been discussed in the previous section regarding the scholarly field of translation studies, and given the dyadic relationship between a text and its translation, originality and authorship must be acknowledged within the act of translation itself, and the source text must be acknowledged as to some degree derivative. The traditional view of originality can, therefore, be understood as a fictional idea, generated from the fact that the target text usually follows the source text in time. However, as Benjamin (1996:254) argues, originality requires translation for its existence, as translation gives the original continued life, "by virtue of the original's translatability." According to Benjamin (1996: 257), "in translation the original rises into a higher and purer linguistic air." The original, in this sense, thus follows rather than precedes translation as it is a concept stemming from translatability. Conferring some of the characteristics of authorship onto translation makes translation a point of departure, and a generative one at that.

Translation creates new authorships as translated books are often presented and performed at events by translators and by whoever else enters those spaces. As Zappino said in an interview, ${ }^{12}$ his translation of Eve Kosofky Sedgwick's Epistemology of the Closet under the title Stanze private. Epistemologia e politica della sessualità (2011), [Private rooms. Epistemology and politics of sexuality], the first translation into Italian of this foundation text of queer theory, invited him to give voice to Sedgwick (and thus impersonate her) at the various presentations of the book in Italy at the time following the publication. ${ }^{13}$

Zappino's presentations of his translation of Sedgwick in 2011 has thus contributed to intensify the debate on queer themes in Italy, along with other events and books, such as the publication in the same year of Queer 
in Italia by Marco Pustianaz, a collection of 25 interviews with Italian queer academics and activists. As a confirmation of this, at the end of 2011, a conference on queer topics took place in Padua, with the title: "Inquietudini Queer" [Queer anxieties]. The call for papers mentions the recent Italian translation of Sedgwick's work as a point of departure for a reflection on eccentricity and what exceeds the norm. Between 2011 and 2013, the "Casa Internazionale delle Donne a Roma" [The International Women's House in Rome] hosted a series of events on queer theory called "Queer it Yourself," organized by the Kespazio collective. The inaugural workshop in December 2011 was dedicated to the discussion of Zappino's translation Stanze private. This is only one example of how translations become entangled in new debates and discussions. Since 2011, interest in queer theory has gained momentum in Italy, as expressed earlier, and this is confirmed by a series of new initiatives dedicated to the topic, not only in LGBTQ spaces, such as the aforementioned collective Smaschiermenti or even the Sommovimento NazioAnale, a network of transfeminist collectives and individuals born in 2012, but also at universities, as shown, for example, by events such as the "Primavera Queer" [Queer Spring] in 2014, a week of discussions and workshops on queer themes at the University of Chieti, ${ }^{14}$ followed by a similar initiative, although shorter, in September 2015 at the University of Padova, entitled "de/Sidera." ${ }^{15}$ A panel organized for the event entitled "Fare e disfare il gender," [Doing and undoing gender] with the participation of Federico Zappino and philosopher Deborah Ardilli, clearly takes inspiration from Zappino's translation of Undoing Gender, with the Italian term "genere" being replaced by the English "gender" in order to discuss via the book the "teoria del gender," thus signaling the foreignness of non-binary/non-heteronormative gender theorizations to Italian culture.

If the presentations of Stanze private might be part of this growing interest in queer theory in Italy, given that Sedgwick is considered one of the most influential queer theorists, then certainly presentations of Fare e disfare il genere have produced similar effects on a larger scale, as they have been more numerous. The book has been presented in various LGBTQ spaces in Italy throughout $2015,{ }^{16}$ and the publicity and the open questions generated at every presentation led to additional presentations. Some of the questions that arose at the book presentations are certainly linked to the debate stirred by the Church and the anti-gender movements against the "teoria del gender." This debate, therefore, was not only involved in preparing the ground for the retranslation of Undoing Gender, as previously argued, but the retranslation, in turn, further intensified the debate. Zappino mentioned in a talk entitled "Sovversione dell'eterosessualità" (2016b) ${ }^{17}$ [Subversion of heterosexuality] the fact that a conservative group, called Giuristi per la vita [Jurists for life], in February 2016 attacked Fare and Disfare il genere at one of their meetings as representing a serious threat to society and to the institution of the family. Moreover, Zappino and Ardilli (2015), in an article written in July 2015 entitled "La volontà di negare" [The will to 
negate], initiated a heated debate among LGBTQ individuals and groups on the type of response that would be most suitable in counteracting the discourses of anti-gender movements. ${ }^{18}$ A popular concept circulating through these discourses is "sexual difference." In this regard, an event, which Zappino attended, was organized by the Women's Library in Padova in April 2016, entitled "Fine della differenza sessuale" [The End of Sexual Difference] (Zappino 2016c), which was inspired by one chapter of Fare e disfare il genere and undertook to discuss the productivity of Butler's work for unraveling such a contentious theme.

As a consequence of the discussions generated by the translation and the networks of people (activists, writers, and translators) it created as a result, a collection of essays, written by this network of people and edited by Zappino, came out in September 2016 with the title Il genere tra neoliberismo e neofondamentalismo [Gender between Neoliberalism and Neofundamentalism]. The book, which has been presented already in various LGBTQ spaces in Italy, investigates the links between the concept of neoliberalism and neofundamentalism, the latter understood as those Catholic and non-Catholic conservative views toward gender, bodies, and sexuality, already discussed with reference to the anti-gender movements. A conference based on the topic of the edited collection and entitled Femminismi e liberismo [Feminisms and liberalism], which also saw the participation of Zappino, was held in December 2016 in Florence. Zappino has just completed the translation of one of Butler's latest books, Notes toward a Performative Theory of Assembly (2015), translated as L'Alleanza dei corpi [The coalition of bodies] (2017), which investigates some of the themes included in the edited collection and the aforementioned conference that will be analyzed further next.

This is all a testament to the performative and citational aspects of translation. Translators are social actors, in line with what theorists of the sociological turn in translation studies affirm, and translations have the capacity of producing new social networks and new queer thought, which generate, in turn, new translations, as indicated earlier.

I would define these social networks mostly as "affective networks," to borrow the words of Italian queer theorist Liana Borghi, judging from the number of intense connections, to borrow the words of Zappino, ${ }^{19}$ that Fare $e$ Disfare il genere gave rise to. Borghi has worked on the topic of affect and made it the subject of some of the summer schools she co-organized with Clotilde Barbarulli in Prato in the first decade of the year 2000, drawing on theorists like Eve Sedgwick and Sara Ahmed. For Sedgwick, affect, especially the affect of shame, which she analyzes thoroughly in her Touching Feeling. Affect, Pedagogy, Performativity (2003), ${ }^{20}$ is performative and is specifically related to notions of queer performativity. Moreover, in this book Sedgwick invokes the tactile aspect of affect as something that touches and that can be touched. The performative aspect of affect is also discussed by communication theorists such as Melissa Gregg and Gregory 
Seigworth (2010). According to them, affect is born in the "in-betweenness" of encounters, in the capacity of acting and being acted upon. Affect produces action, and its performativity lies in the fact that it puts the body into motion, into a perpetual becoming, similar to that doing and undoing movement discussed by Butler. Affects put bodies in contact with each other, and in this sense, they can be considered forces that cut across bodies. Among translation studies scholars, Douglas Robinson, Carole Maier, and Elena Basile discussed the affective engagement by translators with their translations. Robinson (1991) suggests a somatic approach to translation, which he further develops in his book Performative Linguistics (2003) mentioned earlier, arguing for the integration of the translator's experience, feelings, and intuitions in the translation process. Maier (2006) drawing from Douglas, when commenting on her translation of Amanda Labarca's "Desvelos en el alba" (1945), explains that the Labarca's work has physically affected her, it has worked its way into her flesh and blood in the same way that other translations had become integral part of her organism.

Basile (2005: 2) discusses the notion of affect when talking about the translator's affective engagement with the source text, stressing concepts such as desire and the role of the unconscious in the translator's labor. Her emphasis is on psychoanalysis, on the question of the acceptance of the otherness of the unconscious and on the driving force of desire and the unconscious, their performative role, we could add, in the production of translations. Sedgwick (2003), too, talks about drives but makes a distinction between drives and affects, detaching the latter from the instrumentality of the former (as drives need to be fulfilled), while Massumi (2002) states that affects should not be conflated with emotions, as we cannot qualify them. This stresses even more the performative aspect of affect, as in this piece I am not interested in qualifying them but in seeing how they are generated, and what they are capable of producing.

I think that affect, which has not yet been systematically theorized in translation studies, is a fundamental element for understanding the peculiarities of activist translation, especially in queer activist movements with their emphasis on the body/embodiment. Theorizing affect can, for example, shed some light on the reasons that push translators to translate with little or no remuneration. It is often because of entering into contact with each other "affectively," of acting together and gravitating toward each other that a translation project or idea takes shape. There are numerous examples of collaborative translations in queer activist spaces in Italy that confirm these assumptions. ${ }^{21}$ Affect thus produces translations at the same exact moment in which it produces movement across bodies and bodies in movement.

Given these premises, translation as an encounter between texts and bodies becomes a space of doing and undoing, that is to say a performative space, which exposes those who occupy it to constant decomposition and recomposition. Affect is thus a driving force, a performative and queering 
force, that enables the encounter with alterity, as Bermann (2014) and Basile (2005) suggest, affecting the way in which translations are produced and the effects they produce.

\section{Translation as a Precarious Space}

In this section, which takes its inspiration from the title of the afterword to the translation of Undoing Gender by Zappino, I will elaborate a bit more on alterity through the notion of precariousness, which is strictly linked to the aforementioned notions of affect and corporeality.

A retranslation of Butler such as Fare e disfare il genere is motivated by the target culture's need to retell a story in order to tackle current debates centered around the concept of gender, as seen in the previous section. These needs are propulsive forces (Massumi 2002; Gregg and Seigworth 2010) that generate, and are generated from, the encounter between activist translators and theorists, between target culture needs and ideas borrowed from the source culture. It is this friction between attachment and unattachment that makes translation possible, as the following section will make clear.

The Italian retranslation not only situates itself within the debate on "teoria del gender" but also produces other debates and writings on the notion of neoliberalism. It reveals and realizes the potentiality of Butler's work (which is not overtly expressed in the source text), as it anchors the discussion more toward the theme of neoliberal austerity and precariousness/precarity, shown by the title of the collection of essays Il genere tra neoliberismo e neofondamentalismo [Gender between Neoliberalism and Neofundamentalism] (Zappino 2016a), which as a project took its inspiration from Fare e Disfare il Genere. Olivia Fiorilli in her review of Zappino's translation says that Undoing Gender, "if conveniently betrayed, is able to speak not only to queer and transfeminist movements, but also to all social movements that fight the exploitative politics of neoliberalism" (Fiorilli 2014). ${ }^{22}$ This betrayal is the aim of Zappino's afterword. The concept of precariousness, which is mainly delineated in Precarious Life: The Powers of Mourning and Violence, is connected in Undoing Gender (2004c) to the previously expressed idea, of our inherent exposure to others, of our intrinsic vulnerability and interdependence on others.

Our life is thus a precarious life, since it is exposed to the violence, will, and arbitrariness of others. As Zappino says, "gender, by being constantly done and undone by language, relationships, norms, is the place of a permanent crisis and precariousness" (2014: 355). Economic crisis, and existential and material precarity, are therefore emphasized by the translator, as these are the major concerns that queer activist groups (but not only) are preoccupied with in Italy at present. The point made by Zappino in his afterword, and analyzed by Fiorilli and others in the many reviews of Fare e Disfare il genere available online, ${ }^{23}$ is that precariousness is not a neutral concept but is exploited by neoliberal discourse. Such discourse aims at neutralizing the 
concept of precarity by pretending it is egalitarian. According to Zappino, it is through the negation of our intrinsic interdependence on each other that "precariousness can be manipulated in different ways in the processes of production and naturalization of economic and social inequalities" (2014: 358). 24

Why is this the case? Fiorilli (2014) states that Butler's reflection on the limits of the autonomy of the subject represents a fundamental attack against the neoliberal rationality that is based on the ontology of the sovereignity of the subject. For Butler, instead, as clarified already earlier, the subject does not even possess itself, let alone gender or sexuality. Moreover, Fiorilli (2014) links the exploitation of precariousness to the concepts of intelligibility and recognizability, discussed by Butler in Undoing Gender with reference specifically to the lives of queer, trans, and intersex people. In regulating the intelligibility and recognizability of the subjects, gender, and sexuality norms also regulate their different inclusion within the human, by promoting or negating the conditions for livability. Given that recognizability in our neoliberal economy comes mainly through labor (Fiorilli 2014), it becomes clear how the promise of recognizability given by labor based on our subjective characteristics (recognition of one's values and skills) becomes the site for the worst exploitative moves as it makes us agents actively and eagerly involved in this process.

This insistence on economic precarity and crisis, with its links to labor exploitation in Italy, constitutes a departure from Butler's text, a way of undoing its theories and transforming them, creating the conditions for the reconsideration of welfare and social justice in Italy. This is evident from the themes of the edited collection Il genere tra neoliberismo e neofondamentalismo, and of the forthcoming translation of Butler's last book, mentioned earlier. ${ }^{25}$ This is not the only betrayal. The presentations of Fare e disfare il genere often served as an occasion to discuss and undo the neofundamentalist assumptions underlying the so-called "teoria del gender". Although seemingly opposing concepts, neofundamentalism and neoliberalism are very much linked, according to Zappino (2016a: 11), by the fact that both make reference to the concept of nature in order to either naturalize differences (neoliberalism) or establish a hierarchy among them by appealing to the "naturality of sexual categories" (neofundamentalism).

I would like now to link the considerations made earlier about labor precariousness/precarity to translation as labor starting from the term used earlier-betrayal. We know that betrayal has been associated through the years with translation, most famously in the French phrase "les belles infidèles." The phrase presupposes that, if a translation is beautiful, it must be unfaithful. This metaphor recalls the genderization and sexualization of translation in heteronormative and patriarchal terms: translation is a feminine activity potentially either faithful or unfaithful with regard to a hypothetical husband/patriarch (i.e., the source text or the "original"). As stated by feminist translation theorist Lori Chamberlain (1988), this confirms 
translation's status as a secondary activity with regard to the source text (to which male characteristics of prestige and authority were attributed). The neoliberal feminization of labor, a concept discussed by Cristina Morini (2015), can be easily associated with translation labor-often misrecognized, invisible, precarious, badly paid, or volunteer-but that requires high levels of flexibility in order to meet on-the-spot requests and tight deadlines, a flexibility which is more and more considered to be a natural expression of femininity (and for this reason, tends to increase the exploitation of labor).

Fiorilli (2014) states that avoiding the trap of such recognizability is possible only if collective spaces and communities are created that make possible a material and symbolic existence challenging the norms that assign recognition and value in an unequal and discriminatory way. The translation of Zappino's Undoing Gender and all that preceded and followed it in terms of events and discussions generated in LGBTQ venues around Italy, has shown that translation is a collective matter (even more so when it is collaborative although this was not the case discussed here), and that it does not stop once the actual text is translated but continues through the voices of all the individuals that participate in the discourses opened up by the text. It shows that translation can be a propulsive force that can contribute to the creation of affective networks, which in turn produce new discourses and translations.

Theorizing translation as a precarious space of interdependence and of performative and affective undoings, especially for queer activist translators, for whom gender and sexuality are already precarious places, should also make us reflect on how to reassign symbolic and material value to such important labor.

\section{Conclusion}

This chapter has shown that the translation of Undoing Gender into Italian is an interesting case for theorizing the queering potential of translation. The chapter has drawn a comparison between undoing gender and undoing translation, focusing on the queer performative aspect of this undoing. Translations are constantly undone because of their relationship with otherness, with something outside themselves, and this undoing is affective and productive. Affectivity enters the scenario through the awareness of our capacity to be affected and put into motion by others, while productivity is revealed in the way in which translations are the outcome of networks of affect, which in their turn produce other networks. Finally, Butler's text, in order to effectively reach the Italian audience, needed to be undone. This undoing is evident in the discourses produced by the translation, centered both on the debates surrounding conservative and neofundamentalist ideas of gender and sexuality (promoted by the Church and by anti-gender movements), and mostly on the idea of precariousness and precarity, linked to the notion of neoliberalism. The notion of existential 
and material precariousness, based on Butler's notion of vulnerability, has steered Italian debates toward a consideration of welfare and social justice in the actual political climate of austerity with its damaging effects on people's lives. Like the body, translation is a vulnerable and precarious place, but it is through an awareness of this precariousness that resistance and social transformation is possible, including a transformation in the status of translation as labor.

\section{Notes}

1 See Fiorilli 2014, Lamberti and Balzano 2014, and Simone 2014.

2 A short article in Italian on this theme was published by the author of this chapter for magazine Doppiozero (Baldo 2015).

3 As affirmed by Garbagnoli (2014), "Teoria del gender" has been coined as a term at the beginning of the year 2000 by the "Pontificio Consiglio per la famiglia" (a department of the Catholic Church) with the aim of labelling, distorting and deligitimizing research produced in the field of gender studies. The Church, and many other right wing laic groups in Italy who have embraced the same ideas and are defined as the anti-gender group, claim that gender studies, or the so-called ideologia or teoria del gender pose a threat to the natural family. They oppose all those theories that challenge the naturalization of sexuality norms and the claims by feminist and LGBTQ movements.

4 Translator Sergia Adamo, in an email correspondence of January 24, 2017, told the author of this chapter that the title Questione di genere was chosen by the publisher and not be her.

5 Guaraldo discussed this with the author of this article in an email correspondence in January 2017.

6 Guaraldo told the author of this article, in a mail correspondence in January 2017 , that the choice of "disfatta" for the translation was a sort of challenge, which, unfortunately, caused a lot of controversy within LGBTQ groups in Italy.

7 Zappino discussed this with the author of this article in a skype interview with him in September 2014.

8 See endnote 7.

9 For the video of the presentation see CTV Telestreet 2015.

10 On this point, see the review by Schulz 2005 and Gray 2005.

11 In 2015-2016, the California College of the Arts hosted a series of events including a lecture by Judith Butler on February 25 with the goal of questioning the notion of gender in translation. For the programme of the event, see California College of the Arts 2016; for Butler's speech see Butler 2016.

12 The interview was conducted via Skype by the author of this paper in September 2014.

13 The book was presented in June 2011 at the Sicilia Queer Festival in Palermo, at the LGBTQ Centre Maurice in Turin in October 2011, at the LGBTQ centre Ireos in Florence in November 2011, and at the LGBTQ space Cassero in Bologna in December 2011, to name a few (not counting those that took place in the following years, like a presentation that was given within a series of seminars which were called "Qui Quo Queer" organized in Bologna in March 2015).

14 For more information on the event see Chieti Today 2014.

15 The Latin term de-sidera which names the event means "far from the stars." The term desire (from the Latin desiderium) derives from this noun and implies that 
desire is a longing for something which is impossible to reach (as stars are). For more information on the event, see Bioslab 2015.

16 The book was presented at various LGBTQ venues, in cities like Bologna, Milan, Rome, Padua, Florence, Turin, Brescia and others. For the presentation in Milan see Ambrosia 2015 and for the one in Bologna see Libreria delle Donne Bologna 2015.

17 The talk was given in March 2016 in Genua in the last of a series of seminars entitled: "A proposito di gender" [With reference to Gender] organised in collaboration with the journal About Gender. The talk was published in the same year in the magazine "Effimera."

18 Due to the lack of space, the debate surrounding this theme can't be examined in depth in this chapter.

19 I refer to email correspondence of 6 May 2015 between the author of this paper, Zappino and various individuals and groups participating in the presentations of Fare e Disfare il genere.

20 Although she focuses on shame towards the end of the book, she analyses also affects such as joy, interest, and excitement.

21 For example, the queer transfeminist collective Serbilla Serpente, Lafra, Elena Zucchini, Feminoska, and Valentine Braconcini have translated the works of post-porn performer and activist Diana Torres and queer transfeminist Itziar Ziga into Italian.

22 The translation was done by the author of this chapter.

23 On this point, see Simone 2014.

24 The English translation is by the author of this chapter.

25 The new translation project further confirms the performativity of translation discussed in this article.

\section{References}

Ahmed, Sara. 2004. "Affective Economies." Social Text 79 (2): 117-139.

Ambrosia. 2015. "Presentazione di Fare e Disfare il Genere di Judith Butler." Available online at https://ambrosia.noblogs.org/post/2015/02/21/presentazione-difare-e-disfare-il-genere-7marzo-piano-terra-h-1930/ (last accessed January 23, 2017).

Angelelli, Claudia V. (ed.). 2012. "The Sociological Turn in Translation and Interpreting Studies." Translation and Interpreting Studies 7(2): 125-128.

Austin, John Langshaw. 1962. How to Do Things with Words, 2nd edition. Cambridge, MA: Harvard University Press.

Baker, Mona. 2006. Translation and Conflict: A Narrative Account. London and New York: Routledge.

Baker, Mona. 2013. "Translation as an Alternative Space for Political Action." Social Movement Studies 12(1): 23-47.

Baldo, Michela. 2015. "Undoing gender. Il disfarsi e rifarsi della traduzione." Available online at www.doppiozero.com/materiali/teorie/undoing-gender-e-ildisfarsi-e-ri-farsi-della-traduzione (last accessed January 27, 2017).

Basile, Elena. 2005. "Responding to the Enigmatic Address of the Other: A Psychoanalitic Approach to the Translator's Labour." New Voices in Translation Studies 1: $12-30$.

Bassnett, Susan and Peter Bush (eds.). 2006. The Translator as Writer. London and New York: Continuum.

Bassnett, Susan and André Lefevere (eds.). 1990. Translation, History and Culture. London: Pinter. 
Benjamin, Walter. 1996. "The Task of the Translator." In Walter Benjamin: Selected Writings. Volume 1. 1913-1926, edited by Marcus Bullock and Michael W. Jennings, 253-263. Cambridge, MA and London: Harvard University Press.

Bermann, Sandra. 2014. "Performing Translation." In A Companion to Translation Studies, edited by Sandra Bermann and Catherine Porter, 285-297. Hoboken, NJ: Wiley-Blackwell.

Bernini, Lorenzo. 2013. Apocalissi Queer: Elementi di teoria antisociale. Pisa: ETS. Bigliazzi, Silvia, Peter Kofler and Paola Ambrosi. 2013. "Introduction." In Theatre Translation in Performance, edited by Silvia Bigliazzi, Peter Kofler and Paola Ambrosi, 1-26. New York and London: Routledge.

Bioslab. 2015. "de/Sidera. Festival Queer. 23-25 Settembre, Padova." Available online at www.fuxiablock.org/desidera-festival-queer-232425-settembre-padova/ (last accessed August 1, 2016).

Butler, Judith. 1990. Gender Trouble: Feminism and the Subversion of Identity. New York: Routledge.

Butler, Judith. 1993. Bodies That Matter: On the Discursive Limits of "Sex". New York: Routledge.

Butler, Judith. 1997. The Psychic Life of Power: Theories in Subjection. Stanford, CA: Stanford University Press.

Butler, Judith. 2004a. Precarious Life: The Powers of Mourning and Violence. London and New York: Verso.

Butler, Judith. 2004b. Scambi di genere: Identità, sesso e desiderio. Translated by Roberta Zuppet. Milano: Sansoni.

Butler, Judith. 2004c. Undoing Gender. New York and London: Routledge.

Butler, Judith. 2004d. Vite precarie: Contro l'uso della violenza in risposta al lutto collettivo. Edited by Olivia Guaraldo, translated by Annarita Taronna, Laura Fantone, Fiorenzo Iuliano, Caterina Dominijanni, Fabio De Leonardis and Laura Sarnelli. Roma: Meltemi.

Butler, Judith. 2005. La vita psichica del potere: Teorie della soggettivazione e dell'assoggettamento. Translated by Elena Bonini and Carlotta Scaramuzzi. Roma: Meltemi.

Butler, Judith. 2006. La Disfatta del genere. Translated by Olivia Guaraldo. Roma: Meltemi.

Butler, Judith. 2012. Partying Ways: Jewishness and the Critique of Zionism. New York: Columbia University Press.

Butler, Judith. 2013a. La vita psichica del potere: Teorie del soggetto. Translated by Federico Zappino. Torino: Mimesis.

Butler, Judith. 2013b. Questioni di genere: Il femminismo e la sovversione dell'identità. Translated by Sergia Adamo. Roma: Laterza.

Butler, Judith. 2013c. Vite precarie: I poteri del lutto e della violenza. Translated by Olivia Guaraldo. Milano: Postmedia books.

Butler, Judith. 2014. Fare e disfare il genere. Translated by Federico Zappino. Torino: Mimesis.

Butler, Judith. 2015. Notes Toward a Performative Theory of Assembly. Cambridge, MA: Harvard University Press.

Butler, Judith. 2016. "Judith Butler Lecture: Gender in Translation." Available online at www.facebook.com/events/543796032463509 (last accessed January 23,2017$)$. 


\section{Michela Baldo}

Butler, Judith. 2017. L'Alleanza dei corpi. Translated by Federico Zappino. Milano: Nottetempo.

California College of the Arts. "Gender in Translation.” 2016. Available online athttp:// criticaltheory.berkeley.edu/events/event/gender-in-translation/ (last accessed July 30, 2016).

Chamberlain, Lori. 1988. "Gender and the Metaphorics of Translation." Signs 13(3): 454-472.

Chieti Today. 2014. "Primavera Queer dal 5 al 9 maggio alla D'Annunzio." Available online at www.chietitoday.it/eventi/primavera-queer-2147269.html (last accessed January 23, 2017).

CTV Telestreet. 2015. "Fare e disfare il genere, di Judith Butler." Available online at www.ctv.bs.it/2015/03/31/fare-e-disfare-il-genere-di-judith-butler/ (last accessed January 22, 2017).

Derrida, Jacques. 1985. "Des Tours de Babels." Translated by Joseph Graham. In Difference in Translation, edited by Joseph Graham, 165-207. Ithaca, NY and London: Cornell University Press.

Fiorilli, Olivia. 2014. "Butler ai tempi dell'economia della promessa (di riconoscimento)." Available online at http://commonware.org/index.php/gallery/534-butlereconomia-promessa (last accessed August 1, 2016).

Garbagnoli, Sara. 2014. "L'invenzione della teoria del gender." About Gender 3(6): $250-263$.

Gray, Erin. 2005. "Undoing Gender." Available online at http:/uppingtheanti.org/ journal/article/01-undoing-gender/ (last accessed July 30, 2016).

Gregg, Melissa and Gregory J. Seigworth (eds.). 2010. The Affect Theory Reader. Durham, NC and London: Duke University Press.

Guaraldo, Olivia. 2014. "La disfatta del Gender e la questione dell'umano." In Fare e disfare il genere, edited by Judith Butler, translated by Federico Zappino, 9-27. Milano: Mimesis.

Harvey, Keith. 1998. "Translating Camp Talk: Gay Identities and Cultural Transfer." The Translator 4(2): 295-320.

Labarca, Amanda. 1945. Desvelos en el alba. Lima: Cruz del Sur.

Laboratorio Smaschieramenti. Available online at https://smaschieramenti.noblogs. org (last accessed January 10, 2017).

Lamberti, Raffaella e Angela Balzano. 2014. "Fare e difare i generi e le generazioni." Avaliable online at www.lavoroculturale.org/fare-e-disfare/ (last accessed January 23, 2017).

Libreria delle Donne Bologna. 2015. "Fare e disfare il genere, oggi." Available online at https:/libreriadonnebo.wordpress.com/2015/03/16/fare-e-disfare-il-genere-oggi/ (last accessed January 23, 2017).

Maier, Carol. 2006. "Translating as a Body: Meditations on Mediation. Excerpts 1994-2004." In The Translator as Writer, edited by Susan Bassnett and Peter Bush, 137-148. London and New York: Continuum.

Massumi, Brian. 2002. Parables for the Virtual: Movement, Affect, Sensation (Post-Contemporary Interventions). Durham, NC: Duke University Press.

Morini, Cristina.2015. "Se freelance è donna. Doppiozero." Available online at www. doppiozero.com/materiali/lavoro-freelance/se-freelance-e-donna (last accessed July 30, 2016).

Pustianaz, Marco (ed.). 2011. Queer in Italia: Differenze in movimento. Pisa: ETS.

"Queer it yourself" 2011-2013. Available online at https://m.facebook.com/pg/ kespazio/events/?ref=page_internal\&mt_nav=1 
Robinson, Douglas. 1991. The Translator's Turn. Baltimore, MD and London: John Hopkins University Press.

Robinson, Douglas. 2003. Performative Linguistics: Speaking and Translating as Doing Things with Words. New York and London: Routledge.

Schoch Zavaletta, Atticus. 2005. "Undoing Gender: Review." The Comparatist 29(1): 152-153.

Schulz, Dirk. 2005. "Review: Judith Butler. Undoing Gender." Available online at www.genderforum.org/fileadmin/archiv/genderforum/illuminating/review_schulz. html (last accessed July 30, 2016).

Sedgwick, Kosofsky Eve. 1990. Epistemology of the Closet. Berkeley, Los Angeles: University of California Press.

Sedgwick, Kosofsky Eve. 2003. Touching Feeling: Affect, Pedagogy, Performativity. Durham, NC: Duke University Press.

Sedgwick, Kosofsky Eve. 2011. Stanze Private. Translated by Federico Zappino. Roma: Carrocci.

SIL. 2013. "Esposti alla precarietà." Available online at www.rachelemuzio.it/SILPROGETTO/articolo-5/ (last accessed January 10, 2017).

Simone, Anna. 2014. "Fare e Disfare il Genere." Available online at www.alfabeta2. it/2014/12/15/disfare-genere-2/ (last accessed January 23, 2017).

Sommovimento NazioAnale. Available online at https://sommovimentonazioanale. noblogs.org (last accessed August 1, 2016).

Tymoczko, Maria. 2007. Enlarging Translation: Empowering Translators. Manchester: St. Jerome Publishing.

Tymoczko, Maria (ed.). 2010. Translation, Resistance, Activism. Amherst, MA: University of Massachusetts Press.

Von Flotow, Luise. 2012. "Translating Women: From Recent Histories and ReTranslations to "Queerying" Translation, and Metramorphosis." Quaderns: Revista de Traducció 19: 127-139.

Zappino, Federico. 2012. "Dalle stanze private agli spazi comuni. Riflessioni intorno a Eve Kosofsky Sedgwick." Available online at www.lavoroculturale.org/dallestanze-private-agli-spazi-comuni-riflessioni-intorno-a-eve-kosofsky-sedgwick/ (last accessed July 30, 2016).

Zappino, Federico. 2014. "Il genere, luogo precario. Note a margine." In Fare e disfare il genere, edited by Judith Butler, translated by Federico Zappino, 355-367. Milano: Mimesis.

Zappino, Federico. 2015. "Fare e difare il genere, di Judith Butler." Available online at www.ctv.bs.it/2015/03/31/fare-e-disfare-il-genere-di-judith-butler/ (last accessed July 30, 2016).

Zappino, Federico (ed.). 2016a. Il genere tra neoliberismo e neofondamentalismo. Verona: Ombre corte.

Zappino, Federico. 2016b. "Sovversione dell'eterosessualità." Available online at http://effimera.org/sovversione-delleterosessualita-federico-zappino/ (last accessed January 10, 2017).

Zappino, Federico. 2016c. "Fine della differenza sessuale." Available online at http://effimera.org/fine-della-differenza-sessuale-federico-zappino/ (last accessed January 4, 2017).

Zappino, Federico and Deborah Ardilli. 2015. "La volontà di negare. La teoria del gender e il panico eterosessuale." Available online at www.lavoroculturale.org/ la-volonta-di-negare/ (last accessed January 4, 2017). 